\title{
THE USE OF AUDIO-LINGUAL METHOD IN TEACHING LISTENING COMPREHENSION AT THE SECOND YEAR STUDENTS OF SMK YAPIP MAKASSAR SUNGGUMINASA \\ (A CLASSROOM ACTION RESEARCH)
}

\author{
Nurdevi Bte Abdul, Hijrah \\ English Department, Faculty of Teacher Training and Education \\ Muhammadiyah University of Makassar \\ Sultan Alauddin Street No. 259 Makassar, South-Sulawesi, Indonesia \\ wiemal_dj84@yahoo.com
}

\begin{abstract}
Listening is one of the four basic skills in learning foreign language besides listening, reading, and writing. It has been taught since the students entered a junior high school, however, there are some difficulties faced by vocational school students to listen the recording. After doing observation, some teachers say that they still have difficulties to teach listening to students since students are not able to express what are on their minds because their lack of actual language. To help the teachers in teaching listening to students, teachers may use an interesting teaching method to present their teaching materials that also help them in creating fun class. One of the alternative methods is Audio-lingual teaching method. The objectives of the study were to explain the students' ability to recognize word meaning in the context and to recognize the content of text. The design of the research used a collaborative classroom action research (CAR). This kind of research was designed by group which consisted of teacher and researcher from educational university. The place of this research was in SMK YAPIP MAKASSAR. The samples in this research were the students at the second year of class 2 Akuntansi 1. After conducting the research, the students' means score showed the improvement in cycle 2. It is concluded that using audio lingual could help to improve students' listening comprehension.
\end{abstract}

Keywords: listening comprehension, audio lingual, recognizing word meaning and the content of the text, classroom action research

Listening is one of the four basic skills in learning foreign language besides listening, reading, and writing. It has been taught since the students entered a junior high school, however, there are some difficulties faced by vocational school students to listen the recording.

After doing observation, some teachers say that they still have difficulties to teach listening to students since students are not able to express what are on their minds because their lack of actual language. To help the teachers in teaching listening to students, teachers may use an interesting teaching method to present their teaching materials that also help them in creating fun class. One of the alternative methods is Audio-lingual teaching method. 
Due to the fact, it needs some efforts to improve the students' ability in listening. One of the improvements of the listening comprehension deals with the method which is reflected in the material and the way of teaching given to the students. Brown (1994:135) states that this in combination with some new ideas about language learning coming from the disciplines of descriptive linguistics and behavioral psychology went on to become what is known as the Audio-lingual Method (ALM).

Audio-lingual teaching method is defined as a method which emphasizes on repetition of the words to help the students to be able to use the target language communicatively. The purpose of the repetition/drills is to breakdown the troublesome sentences into smaller part. Drilling is a key feature of audio-lingual approaches to language teaching which placed emphasis on repeating structural patterns through oral practice (Brown, 1998: 137).

\section{RESEARCH PROBLEM}

Based on the general background of the study above, the research questions can be stated as:

1. How is the students' ability to recognize word meaning in the context?

2. How is the students' ability to recognize the content of text?

\section{THE CONCEPTS OF AUDIO-LINGUAL METHOD}

Using contrastive The Audio-lingual Method, also known as the aural oral, Functional skills, new key or American method of language teaching was considered a "scientific" approach in language teaching (Lado in Omaggio, 1986:61).

Many people, across the world, showed an intense and abiding interest in modern languages. Dissatisfaction with the traditional methods, their validity, and adequacy, especially with their treatment of spoken language led to the birth of the Audio-lingual method which is based on the aural-oral approach. It put accent on the acquisition of oral language skills through oral practice based on repetition and analogy (Larsen, 2000). 
Haycraft (2002) Audio-lingual theory is derived from linguistics and psychology. It is a combination of structural linguistics theory, contrastive analysis, aural-oral procedures and behaviorist psychology. In this theory language is seen as having its own unique system. The system comprises several different levels: phonological, morphological, and syntactic.

Each level has its own distinctive patterns. Language learning is viewed as the acquisition of a practical set of communication skills. It entails language and learning the rules by which these elements are combined from phoneme to morpheme to word or phrase to sentence. Language is primarily spoken and only secondarily written.

\section{THE PRINCIPLES OF AUDIO-LINGUAL METHOD}

Bushra (2001) describes the principles of the Audio-lingual method as follows:

(1) Instructions are given in the target language

(2) Language forms occur within a context

(3) Students' native language interferes as little as possible with the students' attempts to acquire the target language

(4) Teaching is directed to provide students with a native -speaker like model

(5) Analogy provides a better foundation for language learning than analysis

(6) Errors are carefully avoided because they lead to the formation of bad habits

(7) Positive reinforcement helps the student to develop correct habits (8) students are encouraged to learn to respond to verbal and non-verbal stimuli

(9) The teacher is regarded as an orchestra leader conducting, guiding and controlling the students' behavior in the target language (10) learning foreign language is treated on par with the native language.

\section{TECHNIQUES OF THE AUDIO-LINGUAL METHOD}

Larsen (2000:45-50) provides expanded descriptions of some common or typical techniques closely associated with the Audio lingual Method. The listing here are as follows: 
1. Dialogue memorization. Students memorize an opening dialogue using mimicry and applied role playing.

2. Backward Build-up (Expansion Drill). Teacher breaks a line into several parts; students repeat each part starting at the end of the sentence and "expanding" backwards through the sentence, adding each part in sequence.

3. Repetition drill. Students repeat teacher's model as quickly and accurately as possible.

4. Chain drill. Students ask and answer each other one by one in a circular chain around the classroom.

5. Single-slot Substitution drill. Teacher states a line from the dialogue, and then uses a word or phrase as a "cue" that students, when repeating the line, must substitute into the sentence in the correct place.

6. Multiple-slot Substitution drill. Same as the single slot drill, except that there are multiple cues to be substituted into the line.

7. Transformation drill. Teacher provides a sentence that must be turned into something else, for example a question to be turned into a statement, an active sentence to be turned into negative statement, etc.

8. Question and Answer drill. Students should answer or ask questions very quickly.

9. Use Minimal Pairs. Analysis, teacher selects a pair of words that sound identical except for a single sound that typically poses difficulty for the learners-students are to pronounce and differentiate the two words.

10. Complete the dialogue. Selected words are erased from a line in the dialoguestudents must find and Insert.

11. Grammar games. Various games designed to practice a grammar point in context, using lots of repetition.

\section{THEORETICAL BASIS OF LISTENING COMPREHENSION}

According to Howatt and Dakin (1974), listening is the ability to identify and understand what others are saying. This process involves understanding a speaker's accent or pronunciation, the speaker's grammar and vocabulary, and 
comprehension of meaning. An able listener is capable of doing these four things simultaneously.

Thomlison's (1984) definition of listening includes "active listening," which goes beyond comprehending as understanding the message content, to comprehension as an act of empathetic understanding of the speaker.

Furthermore, Gordon (1985) argues that empathy is essential to listening and contends that it is more than a polite attempt to identify a speaker's perspectives. Rather more importantly, empathetic understanding expands to "egocentric prosocial behavior". Thus, the listener altruistically acknowledges concern for the speaker's welfare and interests.

Ronald and Roskelly (1985) define listening as an active process requiring the same skills of prediction, hypothesizing, checking, revising, and generalizing that writing and reading demand; and these authors present specific exercises to make students active listeners who are aware of the "inner voice" one hears when writing.

\section{CONCEPTUAL FRAMEWORK}

Based on the theoretical in this research, the researcher formulates the conceptual framework as follows:

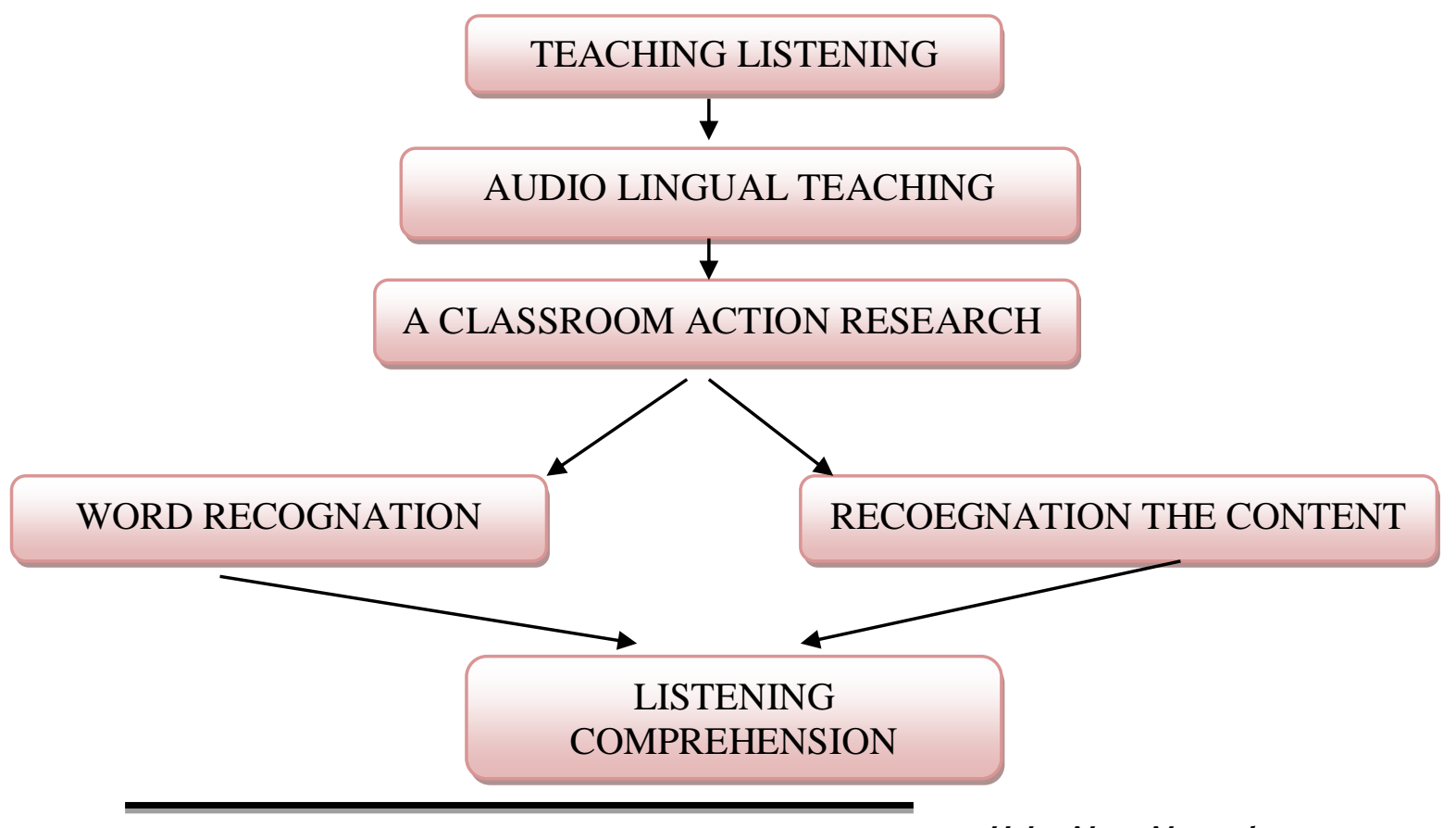

Vol. 2 No. 2 November 2013 
The conceptual framework explains that in teaching and learning process of listening comprehension, the researcher uses Audio Lingual Method to help the students improve their listening comprehension. The researcher focuses on improving the students' recognition of word meaning and content of the text. At the end of lesson, the researcher hopes the students will be able to improve their listening comprehension.

\section{RESEARCH METHOD}

The design of the research used a collaborative classroom action research (CAR). This kind of research was designed by group which consisted of teacher and researcher from educational university.

1. Place

The place of this research was in SMK YAPIP MAKASSAR. The samples in this research are the students at the second year of class 2 Akuntansi 1.

2. Time

This research was conducted from February to May 2014. The researcher conducted the meeting for four times for each cycle.

\section{Research Cycles}

Action research was through many repeated cycles and there were at least two cycles in action research. Each cycle consisted of four steps; planning, action, observation, and reflection.

In this research there are two variables, namely independent variable and dependent variable. Independent variable is teaching listening skill by using Audio Lingual Method and dependent variables are the students' ability to:

1. Recognize the word meaning

a) The students are able to recognize the synonym of the word

b) The students are able to recognize the antonym of the word

2. Identify the content of the text

a) The students are able to identify main idea of the story.

b) The students are able to identify supporting idea of the story. 


\section{Research Instrument}

There are two instruments used in this research namely observation sheet and test. Observation sheet aims at findings out the students' data about their presence and activeness in teaching learning process. Test aims to get information about students' improvement after teaching learning process by using Audio Lingual Method.

\section{Research Procedures}

This research action procedure consists of two cycles namely the first cycle of meetings held four times consisting of the learning process and the test cycle I; and cycle II will be held for four meetings consisting the learning process test cycle II. In accordance with the nature of Tick-class research, the research on the second cycle conducts of the lack to improve in cycle I. Each cycle of four stages namely: Planning, Action, Observation, Evaluation, and Reflection.

a. Planning

1) Understanding the curriculum of the university and analyzing it to know basic competency and apply to the students by using Audio Lingual Method.

2) Making lesson planning based on the syllabus and preparing material of lesson planning and it should base on the teaching of listening skill.

3) Making observation paper to observe the students activity.

4) Making instrument evaluation that used in the classroom.

b. Action

1) In the first step, students will listen to a native-like model such as the teacher of a tape recorder and the students repeat the new material chorally and individually.

2) The next step, the students will memorize an opening dialogue using mimicry and apply role playing. 
3) Then, teacher will break a line into several parts; students repeated each part starting at the end of the sentence and "expanding" backwards through the sentence, adding each part in sequence.

4) After that, the teacher will come to "Repetition drill". The students repeat teacher's model as quickly and accurately as possible.

5) And then, the students will ask and answer each other one by one in a circular chain around the classroom. The teacher states a line from the dialogue, and then uses a word or phrase as a "cue" that students, when repeating the line, must substitute into the sentence in the correct place.

6) Teacher will provide a sentence that must be turned into something else, for example a question to be turned into a statement, an active sentence to be turned into negative statement, etc.

7) Teacher will select a pair of words that sound identical except for a single sound that typically poses difficulty for the learners-students are to pronounce and differentiate the two words.

8) In the last step, the students will complete the dialogue. Selecting words are erased from a line in the dialogue-students must find and insert.

c. Observation

1) Making a note for all the activities of the students in every meeting in order that the teacher can measure the improvement of the students' skill.

2) Identification and make note all the problem that we need when teaching and learning process based on observation paper that has arranged.

3) Making the evaluation which used the result of the study to know how far their improvement.

4) Giving the students' chance for giving suggestion in action research.

d. Reflection

After collecting the data, the teacher evaluated the teaching learning process. Then, the teacher reflected herself by seeing the result of the observation, whether the teaching learning process of reading through Audio Lingual Method to 
improve the students listening skill. If the second plan was unsuccessful the teacher made the next plan to get the result.

\section{FINDINGS}

In the following table shows the students' ability to listening comprehension in diagnostic test, first cycle and second cycle. 
1. The students' ability to recognize word meaning in the context

\begin{tabular}{|l|c|c|c|}
\hline \multicolumn{1}{|c|}{ Indicator } & Cycle 1 & Cycle 2 & Improvement \\
\hline $\begin{array}{l}\text { Recognizing word } \\
\text { meaning }\end{array}$ & 214 & 226 & $5.61 \%$ \\
\hline
\end{tabular}

The table above shows the students' means score in cycle 1 and cycle 2 in recognizing word meaning. In teaching process the researcher applied audio visual as a media to improve students' listening comprehension. The data in cycle 1 indicates students' mean score is 214 and it improves in cycle 2 to be 226 . By calculating those score, it shows the improvement from cycle 1 to cycle 2 is $5.61 \%$. It means that applying audio visual in teaching could improve students' listening comprehension, especially in recognizing words meaning.

2. The students' ability to recognize the content of the text

\begin{tabular}{|c|c|c|c|}
\hline Indicator & Cycle 1 & Cycle 2 & Improvement \\
\hline $\begin{array}{l}\text { Recognizing the } \\
\text { content of the text }\end{array}$ & 220 & 230.5 & $4.45 \%$ \\
\hline
\end{tabular}

The table above shows the students' means score in cycle 1 and cycle 2 in recognizing the content of the text. In teaching process the researcher applied audio visual as a media to improve students' listening comprehension. The data in cycle 1 indicates students' mean score is 220 and it improves in cycle 2 to be 230.5. By calculating those score, it shows the improvement from cycle 1 to cycle 2 is $4.45 \%$. It means that applying audio visual in teaching could improve students' listening comprehension, especially in recognizing words meaning.

\section{CONCLUSIONS}

Listening is one of the four basic skills in learning foreign language besides listening, reading, and writing. It has been taught since the students entered a junior high school, however, there are some difficulties faced by vocational school 
students to listen the recording. After conducting the research, the students' means score showed the improvement in cycle 2. It is concluded that using audio lingual could help to improve students' listening comprehension.

\section{REFERENCES}

Anderson, Stephen C.1985. "Animate and inanimate pronominal systems in Ngyemboon-Bamileke." Journal of West African Languages 15(2): 61-74. Brown. A and Dowling. P.1998. Doing Research/Reading Research: A mode of Interrogation for Education. London: The Falmer Press.

Brown, James Dean. 1988. Understanding Research in Second Language Learning. United States of America: Cambridge University Press.

Bygate, Martin.2000.Teaching and Researching Speaking. London: Longman. Derewianka, Beverly.1990.Exploring How Texts Work. London: Primary English Teaching Association.

Direktorat Jenderal Pendidikan Dasar dan Menengah, Direktorat Pendidikan Lanjutan Pertama.2004.Pelajaran Bahasa Inggris Kelas VII. Jakarta: Dit.PLP, Ditjen Dikdasmen, Depdiknas

Feyten, C. M. (1991). The Power of Listening Ability: An Overlooked Dimension in Language Acquisition. The Modern Language Journal 75:173-80.

Gay, L. R.1987. Educational Research. Columbus: McMillan Publishing Company.

Gronlund, Norman. E.1982. Constructing Achievement Tests. USA: Prentice Hall, Inc.

Harmer, Jeremy. 2001. The Practice of English Language Teaching. London: Longman.

Harris, P. David. 1969. Testing English as a Second Language. USA: McGrawHill, Inc.

Haycraft, John. 2002. An Introduction to English Language Teaching. London: Longman.

Heaton, J.B.1984.Writing English Language Tests. London: Longman. 
Johnson. D. M. 1987. Approaches to Research in Second Language Learning. London: Longman Group Ltd. 